\title{
A globalização do terrorismo e seus reflexos para a América latina e Caribe
}

\author{
La globalización del terrorismo y sus reflejos para Latinoamérica y Caribe
}

\author{
The globalisation of terrorism and its reflexes to Latin America and the \\ Caribbean
}

\begin{abstract}
André Luís Woloszyn ${ }^{1}$
Resumo

O presente artigo faz uma análise crítica acerca da globalização do terrorismo com base em conceitos e controvérsias no âmbito da Organização das Nações Unidas. Examina três períodos cronológicos distintos para identificar em qual destes teria surgido a expressão globalização do terrorismo e de que maneira se ampliou para outras regiões e, em especial, seus impactos e perspectivas para a América Latina e Caribe. O tema torna-se relevante, em razão de sua inserção na agenda política internacional como tendência para futuros conflitos bélicos, sendo considerado uma ameaça à paz e à segurança global.
\end{abstract}

Palavras-chave: Terrorismo; Segurança; Globalização; Perspectivas; América Latina.

\section{Resumen}

El presente artículo hace un análisis crítico sobre la globalización del terrorismo con base en conceptos y controversias en el ámbito de la Organización de las Naciones Unidas. Examina tres períodos cronológicos distintos para identificar en cuál de estos habría surgido la expresión globalización del terrorismo y de qué manera se amplió a otras regiones y, en especial, sus impactos y perspectivas para Latinoamérica y Caribe. El tema se vuelve relevante, por el hecho de su inserción en la agenda política internacional como tendencia para futuros conflictos bélicos, al estar considerado una amenaza a la paz y a la seguridad global.

Palabras clave: Terrorismo; Seguridad; Globalización; Perspectivas; Latinoamérica.

\begin{abstract}
The present article is a critical analysis of the globalisation of terrorism on the basis of concepts and controversies that are found in the United Nations Organisation. The article examines three different periods of time in order to identify in which of them the phrase 'globalisation of terrorism' has likely arisen. It also investigates the way in which it has spread to other regions and, in particular, its impact and perspectives for Latin America and the Caribbean. This theme becomes relevant due to its presence in the international political agenda as a tendency towards future warlike conflicts with it being considered a threat to world peace and safety.
\end{abstract}

Keywords: Terrorism; Safety; Globalisation; Perspectives; Latin America

\footnotetext{
${ }^{1}$ É Analista de Assuntos Estratégicos, Mestre em Direito pela UniRitter Laureate International Universities, Pósgraduado em Ciências Penais pela Universidade Federal do Rio Grande do Sul, diplomado em Inteligência Estratégica pela Escola Superior de Guerra. E-mail: alwi.war@gmail.com
} 


\section{Introdução}

O terrorismo é um fenômeno de violência milenar bem anterior aos períodos da Santa Inquisição ou das guilhotinas na revolução francesa, embora tenha sido neste último que a expressão foi popularizada e utilizada como instrumento político estatal.

Durante a Guerra Fria, (1945 à 1990) não se poderia afirmar que havia uma globalização pois os grupos tidos como do terrorismo clássico eram essencialmente locais com objetivos delineados. Todavia, a invasão soviética no Afeganistão e o consequente treinamento e financiamento de grupos de resistência, em especial, por parte de países ocidentais, deram o primeiro passo para o status quo dos grupos terroristas de cunho extremista islâmico.

Com a ascensão da Al Qaeda e os atentados de grande impacto como o do 11 de setembro, o terrorismo ganharia maior relevo. E outros episódios que se seguiram como os do metro de Madri (2004), do metro de Londres (2005), desencadearam um sentimento de vulnerabilidade permanente, uma sensação de que vivemos em um mundo cercado de violência imprevisível e indiscriminada. Esta sensação é de certa forma real, em parte, pelos ataques mutáveis e sem fronteiras do terrorismo internacional, com objetivos difusos e cujos alvos são, preferencialmente, a população civil utilizada como apelo midiático para propaganda.

O fenômeno recrudesceria com o surgimento do Islamic State of Iraq and Syria (ISIS) ou Estado Islâmico, como é conhecido no Ocidente, durante a invasão do Iraque pelas tropas de coalizão. Trata-se de uma organização mais estruturada, com elevado profissionalismo e uma estratégia clara na disputa de poder, utilizando-se da religião islâmica como pretexto e ao mesmo tempo escudo para legitimar suas atividades na guerra civil da Síria e do Iraque.

Uma globalização parcial ocorreria ao longo desse cenário fragmentado. A responsabilidade não recai exclusivamente nos grupos terroristas que possuem uma percepção distorcida do mundo e do conceito de jihad, manifestado por meio de ações de violência extrema mas, sobretudo, de parte dos países envolvidos diretamente com o fenômeno que enfrentam dificuldades em lidar com esta ameaça.

Diante desta conjuntura, o objetivo do presente artigo é analisar resumidamente como surgiu e como se efetivou a expressão globalização do terrorismo. Para tal desiderato, parte de definições conceituais e examina o contexto histórico do ambiente internacional a partir da década de 60. Conclui argumentando acerca dos possíveis reflexos e perspectivas desta globalização, particularmente, para a América Latina e região do Caribe. 


\section{Conceitos e controvérsias}

Uma primeira pesquisa etimológica revela que a busca por um conceito amplo onde estejam inseridos todos os componentes delituosos de uma ação terrorista assim como seus efeitos colaterais é tarefa impossível. Esta constatação recai em aspectos característicos do fenômeno ora estudado como a multidisciplinariedade, a dinâmica das ações, a subjetividade dos critérios de avaliação e as diferentes motivações.

Tal constatação é corroborada por Alex Schmid (1983) que em pesquisa realizada no ano de 1983, apurou a existência de 109 definições e estabeleceu a frequência de seus elementos definidores com base em 22 palavras mais citadas. A violência e força aparecem com $83,5 \%$ seguido do político com $65 \%$, o medo com ênfase no terror com $51 \%$ e a ameaça com 47\%. (SCHMID,1883, p.136).

No magistério de Lyman e Potter (2004) terrorismo é definido como:

Uma violência grave cometida com qualquer meio, que provoca morte, lesões corporais ou graves prejuízos à propriedade, contra pessoas inocentes com o objetivo de causar tais consequências, direta ou indiretamente, e obter, pela coação ou intimidação de alguns grupos específicos ou governo, ou qualquer outro similar, benefício de natureza política, militar, religiosa ou filosófica, e sem qualquer justificação ou escusa. (LYMAN E POTTER, 2007, p.326)

Cretella Neto (2007) reproduz um conceito elaborado pela Comissão Europeia, após os atentados do 11 de setembro de 2001, cujas condutas delitivas atribuídas ao terrorismo já estão relacionadas na legislação criminal interna de seus Estados-membros:

Uma lista de violações tratadas como atos de terrorismo quando cometidas intencionalmente por indivíduos ou grupos contra um ou mais países ou suas instituições ou população, com a finalidade de ameaçá-los e seriamente enfraquecer ou destruir suas estruturas políticas, econômicas ou sociais. (CRETELLA NETO, 2007, p.376)

No âmbito da Organização das Nações Unidas, a Resolução $n^{\circ} 1.566$, de 8 de outubro de 2004, do Conselho de Segurança das Nações Unidas, define terrorismo da seguinte maneira:

(...) atos criminosos, inclusive contra civis, cometidos com o fim de causar morte ou lesão corporal grave ou de tomar reféns, de forma a provocar estado de terror no público em geral ou em um grupo de pessoas, intimidar uma população ou compelir um governo ou organização internacional a praticar ou deixar de praticar qualquer ato. 
Vale destacar, que a Assembleia Geral da ONU já o havia definido anteriormente por meio da Resolução no 51/210, datada de 1996, como sendo um ato criminoso praticado com a intenção de provocar um estado de terror no público em geral, um grupo de pessoas ou de pessoas específicas com objetivos políticos. Todavia, no período pós-11 de setembro, o conceito seria ampliado segundo as novas características que estudaremos adiante.

Por outro lado, em linha de pensamento distinta nesse tema, surge a corrente defendida por Eric Hobsbawm, Walter Laqueur e David J. Whittaker, dentre outros, que considera o terrorismo uma estratégia hegemônica das nações desenvolvidas, como justificativa para práticas intervencionistas em estados débeis, assevera que não existe uma definição consensual para o terrorismo.

Nesta mesma linha, Hoffman (1998) amplia o debate quando advoga que a denominação parece depender, essencialmente, de um ponto de vista:

A decisão de rotular uma organização terrorista é subjetiva, dependendo largamente da simpatia com ou da oposição à pessoa ou grupo em questão. Se alguém se identifica com a vítima da violência, por exemplo, então é terrorismo. Se, porém, alguém se identifica com o autor, o ato violento é visto de forma mais solidária, quando não positiva, não é terrorismo. (HOFFMAN, 1998,p.31)

Diante deste contexto, existe um amplo cardápio de controvérsias envolvendo a questão do terrorismo e dois importantes pontos merecem maior reflexão. O primeiro situa-se na razão de sua definição uma vez que não existe um conceito universalmente aceito pelos Estados-Membros da Organização das Nações Unidas, e neste sentido, se pode afirmar que cada Estado possui sua própria definiçãa.

Uma das possíveis explicações para a falta de consenso é apresentada por Alcaide Fernández (2000) quando aduz que:

Cada estado percibe el terrorismo en función de su experiencia histórica, de los valores básicos asumidos y de las prioridades em las relaciones con otros estados, hasta el punto de que hablar de comunidade internacional pude parecer retórico. (ALCAIDE FERNÁNDEZ, 2000, p.28)

O segundo ponto recai na polêmica de ser este, uma ameaça externa, portanto, uma guerra combatida com forças armadas como defende os EUA, ou uma ameaça interna e questão de segurança pública, como entende a Comunidade Europeia.

Dworkin (2009) considera esta ambiguidade como o ponto central das divergências entre os EUA e a União Europeia: 
(...) los estadounidenses vem el terrorismo principalmente como una amenaza externa, mientras que para las sociedades europeas tiene en gran medida una dimención interna. La administración Bush presentó la lucha contra los grupos terroristas como una guerra (...) para la EU es sobre todo un problema relacionado con el cumprimento de la ley. (DWORKIN, 2009, p.80)

De um ponto de vista mais crítico, a tese defendida pelos EUA acarreta sérias consequências jurídicas além de um dilema ético e moral entre os dois continentes uma vez que na Europa, a legislação é clara a respeito das condições em que devem ser realizadas prisões, interrogatórios e transferência de presos para outros países. Caso o terrorismo internacional fosse considerado um conflito armado, determinaria aos EUA, a aplicação das regras da Convenção de Genebra em relação ao tratamento de prisioneiros, em consonância com o direito internacional, tese defendida pela UE. Caso fosse considerado um crime de guerra, conforme prescreve o artigo $8^{\circ}$ do Estatuto do Tribunal Penal Internacional, a competência para julgamento estaria sob o guarda-chuva deste e não de tribunais militares como ocorre atualmente. Contudo, tais condições ainda estão indefinidas.

Varvin (2003), a seu turno, vai além quando sustenta que o terrorismo é um fenômeno mais complexo do que se pode esperar:

(...) não pode ser entendido apenas como fenômenos sociológicos como a pobreza e disputas políticas pelo poder, o que seria um raciocínio meramente simplista. Sob o ponto de vista da psicanálise, estes atos envolvem uma relação perturbada com outros seres humanos em níveis moral, ético e emocional fomentada por discursos ideológicos e religiosos. (VARVIN 2003, p.48)

Neste sentido, a demonstração mais clara desta assimetria comportamental pode ser observada nos recentes e sistemáticos atentados de baixa intensidade ocorridos na Europa como os atropelamentos coletivos e as ações com armas de uso caseiro patrocinados por autóctones, muitos destes, meramente simpatizantes da ideologia do ISIS e ou inconformados com as condições sociais que vivem em seus países.

\section{Contexto histórico}

\subsection{Os revolucionários ou terrorismo clássico}

Quando o enfoque entra no campo da globalização do terrorismo, há que se fazer, necessariamente, uma divisão entre três períodos históricos distintos. A primeira fase operou entre as décadas de 60 a 80, envolvendo grupos de cunho separatista e nacionalista como as Brigadas Vermelhas na Itália, o IRA na Irlanda, o ETA na Espanha e o Baader Meinhof, na 
República Democrática Alemã, financiados, em parte, pela extinta União Soviética com o objetivo de desestabilizar o regime político nestes países.

A América Latina seguiu esta mesma linha com o surgimento de diversos grupos armados similares em praticamente todos os países.

A lição de Woloszyn (2010) elenca alguns destes grupos em seus respectivos países:

No México, o Exército Zapatista de Libertação Nacional, o Exército de Libertação Nacional e as FARCS na Colômbia, o grupo Puka Inti no Equador, o grupo Tupac Katari na Bolívia, a Frente Patriótica Manoel Rodrigues no Chile, o Sendero Luminoso e Tupac Amaru no Peru, os Montoneiros na Argentina, Tupamaros no Uruguai além da Vanguarda Revolucionária Popular e da Vanguarda Revolucionária Palmares, no Brasil. (WOLOSZYN, 2010, p.26)

Na década de 80, a região do Caribe tornou-se um campo de violência brutal do terrorismo de Estado, patrocinado pelos EUA, contra grupos de resistência e governos simpatizantes e ou alinhados da URSS com massacres na Nicarágua e em El Salvador, a exemplo do que ocorreu na Guatemala em 1954. Segundo Chomsky (2006) as ações militares na Nicarágua, embora condenadas pela Corte Internacional de Justiça em 1986, pelo uso ilegal da força e por uma guerra econômica ilegal, foram recebidas a época com irrelevância. (CHOMSKY, 2006, p.204-211)

Vale destacar, que tais grupos eram classificados como revolucionários e seus integrantes considerados subversivos, envolvidos em uma luta político-ideológica de contestação. A expressão terrorista era pouco explorada, inclusive, pela imprensa internacional, embora tenham efetivamente praticado ações terroristas dentro de um contexto de violência maior. Tampouco, havia a intervenção da Organização das Nações Unidas (ONU), que a considerava uma questão criminal de caráter interno dos países, dentro do princípio da soberania surgido em 1948, com o tratado da Westphalia. Este entendimento, como vimos anteriormente, ainda vigora na Comunidade Europeia.

O mesmo ocorria com os oriundos da região do Oriente Médio como a Irmandade Muçulmana no Egito, o Hamas na Faixa de Gaza e Cisjordânia, o Hizbollah no Líbano e a Frente Popular para a Libertação da Palestina na Síria. Apoiados pelo Iraque, Irã, Síria e Líbano, tratava-se, basicamente, de células de resistência política com atuação interna tendo como alvos seletivos autoridades governamentais e outras personalidades locais.

Contudo, com o esfacelamento do império soviético em 1989 e o fim da bipolaridade mundial, os revolucionários europeus e das Américas perderam força e legitimidade. A maioria dos grupos foi extinta, devido ao fim do financiamento soviético e também por força 
da nova fase de independência das ex-colônias europeias e da democratização que vigorava nos países da América Latina.

Silva (2003) corrobora com esta afirmação aduzindo que:

É inegável que, superada a confrontação ideológica do período da guerra fria, e praticamente finalizado o processo de lutas em prol das independências das excolônias europeias, o recurso a ações armadas foram perdendo cada vez mais legitimidade como instrumento de contestação. (SILVA, 2003, p.249)

Tal conjuntura, coincidiu com o início do processo de globalização econômica que acarretou em novos paradigmas de violência e ameaças globais mais complexas, como advertiu Michel Wieviorka (1997) em sua obra que redimensiona o conceito de violência face a globalização mundial. Dentre elas, além do terrorismo, a diversificação da criminalidade transnacional diante de novos mercados emergentes. Em decorrência, segmento expressivo destes revolucionários migraram para esta nova dinâmica passando a integrar e ou assessorar organizações criminosas ligadas ao narcotráfico e tráfico de armas na América Latina.

\subsection{Os terroristas}

A perda de legitimidade dos revolucionários não afetaria os grupos oriundos do Oriente Médio. O ano de 1972 inauguraria uma fase de transição entre o terrorismo clássico e o novo terrorismo, praticado por grupos extremistas de natureza religiosa.

Vale lembrar, que nesta data, ocorreu o atentado do grupo palestino Setembro Negro, ligado a Organização de Libertação da Palestina (OLP) contra os atletas israelenses na Olimpíada de Munique. O episódio, com forte apelo televisivo, foi utilizado como propaganda da causa palestina junto a opinião pública internacional e fonte de inspiração para outras facções terroristas.

Posteriormente, ocorreram outros ataques de repercussão internacional como os atentados ao quartel dos fuzileiros navais dos EUA no Líbano em 1983, a explosão do carrobomba na sede da embaixada israelense em 1992 e na Associação Mutual Israelita Argentina (AMIA) em 1994, ambos em Buenos Aires. Além destes, merecem registro os carros-bomba nos prédios da embaixada dos EUA em Nairobi (Quênia) e em Dar el Salam, (Tanzânia) em 1998.

Por sua sistematicidade, tais episódios foram o primeiro passo para o conceito de globalização do terrorismo, despertando a atenção dos EUA para a América Latina acerca da possibilidade da presença de células terroristas originadas no Oriente Médio na região da Tríplice Fronteira entre Brasil, Argentina e Paraguai. Em especial, o Hamas e Hizbollah que supostamente estariam envolvidos nos atentados de Buenos Aires. 


\subsection{O radicalismo islâmico}

As investigações e o interesse dos EUA na região sul-americana seriam intensificados com os atentados do 11 de setembro, praticados pela rede Al Qaeda sob a liderança de Osama Bin Laden, episódio que deu início a terceira fase, classificada como terrorismo de natureza extremista islâmico. Nela, os alvos passaram a ter um caráter mais amplo e simbólico deixando de atingir apenas personalidades públicas e autoridades governamentais para uma natureza indiscriminada.

Surge, então, pela primeira vez o discurso sobre a internacionalização do terrorismo com o termo jihad global, defendido por Bin Laden. A amplitude desta ameaça obteve eco no âmbito do Conselho de Segurança as Nações Unidas que deu início a uma contraofensiva global. Com o apoio de uma força de coalizão internacional, os EUA deram início a uma ampla campanha política e militar para desmantelar a rede terrorista Al Qaeda, culminando com a intervenção no Afeganistão em 2001 e a invasão do Iraque em 2003.

Paulatinamente, foi relançada em 2002, A Estratégia de Segurança Nacional dos Estados Unidos da América, batizada de doutrina Bush, baseada nos conceitos de supremacia militar e ataque preventivo, enfatizando seu uso contra países considerados inimigos e contra grupos terroristas internacionais, independente da região e das fronteiras em que se encontrassem. Denominada pelo então Presidente, George W. Bush de guerra ao terror constituiu-se de um esforço concentrado que mobilizou diversos países em vários campos, especialmente ações de inteligência e contra inteligência, combinada a operações militares de larga escala.

A Al Qaeda retaliou estas iniciativas com três diferentes atentados de grande impacto que atingiriam a sede da ONU em Bagdá (2003) o metro de Madri (2004) e logo em seguida, o metro de Londres e a cidade turística de Bali (2005). Os episódios ocorridos na Espanha e Reino Unido, países que possuíam, pretensamente, um avançado sistema de segurança contra este tipo de ameaça, demonstrou o quanto estavam vulneráveis a grupos terroristas da nova ideologia que se apresentava com o radicalismo islâmico. Tais governos sofreram pressões políticas e críticas da opinião pública interna pela ineficiência demonstrada pelos órgãos de segurança e inteligência, no sentido de não preverem antecipadamente os atentados.

Desta forma, o esforço concentrado entre diferentes nações seria incrementado e ratificado o discurso da globalização do terrorismo na busca de maior apoio político, militar e de ações de inteligência de parte dos demais Estados-membros da ONU. 


\section{Os EUA e o Conselho de Segurança da ONU contra o terrorismo}

A participação dos EUA na guerra contra o terrorismo internacional foi e ainda é predominante, em especial, seu grau de influência política no Conselho de Segurança das Nações Unidas.

Para ratificar tal afirmação basta atentarmos para o fato de que, entre os anos de 2001 à 2006, das 38 Resoluções do Conselho que tratam do terrorismo internacional, 22 foram elaboradas pós-11 de setembro.

Dentre estas, merecem maior destaque as reproduzidas no quadro abaixo:

\begin{tabular}{|c|c|c|}
\hline RES/CSNU & ANO & ASSUNTO \\
\hline 1373 & 2001 & $\begin{array}{l}\text { Considera todo o ato terrorista como uma ameaça à paz e à segurança } \\
\text { internacional. Impôs inúmeras obrigações a todos os Estados-membros acerca das } \\
\text { atividades de financiamento ao terrorismo, do controle mais rígido de fronteiras, } \\
\text { fomento à cooperação internacional e a proibição do envolvimento de Estados } \\
\text { com grupos terroristas, além de criar o Comitê Contraterrorismo (CTC), } \\
\text { responsável pela fiscalização e implementação destas disposições. }\end{array}$ \\
\hline 1540 & 2004 & $\begin{array}{l}\text { Instituiu diversas obrigações acerca da não proliferação de armas de destruição } \\
\text { em massa (biológicas, químicas ou nucleares), no sentido de evitar que viessem a } \\
\text { ser empregadas por grupos terroristas. }\end{array}$ \\
\hline 1624 & 2005 & Criminaliza os atos de incitamento ao terrorismo. \\
\hline 2178 & 2014 & $\begin{array}{l}\text { Reconhece que o terrorismo não pode ser vencido exclusivamente com a força } \\
\text { militar, sugerindo uma série de medidas de segurança interna adicionais para os } \\
\text { demais países-membros. Trata do recrutamento de pessoas com objetivo de } \\
\text { cometer atos de terrorismo, prevendo que os Estados devem tomar as medidas } \\
\text { necessárias para prevenir e combater esse perigoso fluxo transnacional. }\end{array}$ \\
\hline 2368 & 2017 & $\begin{array}{l}\text { Condena todos os atos terroristas ao redor do mundo ordenado medidas para } \\
\text { congelamento de bens, proibição de viagens e embargo de armas em relação a } \\
\text { indivíduos associados à grupos terroristas. }\end{array}$ \\
\hline
\end{tabular}

Fonte: WOLOSZYN e FERNANDES, 2017, p. 166-167.

Ademais, o Congresso dos EUA promulgou uma nova legislação, o Act Patriot, contendo uma série de medidas para combater o terrorismo, ainda vigentes. O objetivo principal é a identificação e neutralização de integrantes de grupos terroristas internacionais, especialmente da rede $A l$ Qaeda e, mais recentemente, do Estado Islâmico por meio da ampliação dos poderes das agências de segurança e inteligência nos quesitos vigilância, monitoramento e espionagem sem a necessidade de uma autorização judicial.

Na visão de Woloszyn e Fernandes (2017) outro ponto polêmico se refere a regra Seven-Day. Nela, caso o Procurador-Geral entender que um estrangeiro seja suspeito de terrorismo ou se constitua em uma ameaça a segurança nacional, o Serviço de Imigração e Naturalização poderá detê-lo sem acusação por até 07 dias, mesmo que este não possua nenhum tipo de registro criminal em seu país de origem. (WOLOSZYN e FERNANDES,2017, p.69) 
Na esteira desta legislação foram criadas a Lei C-36/2001, atual Bill S-7, no Canadá, a Lei nº114-FZ/2002, aprovada pela Duma na Federação Russa e a Lei 375-168/2008 na Alemanha. Tais dispositivos legais são objeto de críticas de opositores destes governos e ativistas dos direitos humanos, em especial, quanto a perda de privacidade dos cidadãos, uma vez que, segundo estes, algumas medidas previstas nas referidas leis colidem com os princípios constitucionais daqueles países e com artigos de tutela e proteção de direitos inseridos na Declaração Universal dos Direitos Humanos de 1948.

No Reino Unido, o Terrorism Act foi aprovado pelo parlamento britânico em 2000, com vigência também na Escócia e País de Gales. Tem por finalidade substituir dispositivos anteriores sobre terrorismo e medidas temporárias empregadas na Irlanda do Norte, quando da atuação do IRA. Foi baseado no anexo $7^{\circ}$ desta lei, que ocorreu a detenção do brasileiro, David Miranda, no aeroporto Heathrow, em 23 de agosto de 2013, por suspeita de envolvimento indireto com o terrorismo internacional ao portar arquivos com documentos sigilosos expondo a política de inteligência norte-americana de combate ao terrorismo.

Quanto a ONU, e as decisões de sua Assembleia Geral acerca do terrorismo, se pode afirmar, que há esforços evidentes em manter as ações de Antiterrorismo e Contraterrorismo adotadas pelos Estados-membros dentro dos limites da legalidade. Todavia, tais decisões, além de não possuírem efeito jurisdicional sobre os demais integrantes ainda podem ser bloqueadas pelo poder absoluto de veto exercido pelos cinco membros permanentes do Conselho de Segurança. (HOBSBAWN, 2007, p.58)

É necessário ressaltar, que segundo a Carta da ONU, os países-membros estão proibidos de empregar a força dentro de outro país sem o consentimento deste, o que é considerado invasão de soberania territorial. A exceção que a ONU permite diz respeito apenas para a autodefesa, conceito igualmente questionável e objeto de polêmicas. Mesmo diante destas recomendações, os países da coalizão permaneceram com sua estratégia de contraofensiva no Iraque, Afeganistão, Paquistão, Somália e Iêmen.

\subsection{Evolução dos ataques e vítimas fatais do terrorismo internacional}

$\mathrm{Na}$ medida em que cresce o número de resoluções do Conselho de Segurança na tentativa de frear as novas dinâmicas do terrorismo, observa-se a intensificação dos atentados praticados pela rede Al Qaeda e grupo Estado Islâmico. No biênio 2014-2015, por exemplo, a evolução no número de atentados e de vítimas fatais atingiu seu maior pico, em parte, como consequência do conflito na Síria. 
Dados estatísticos colhidos do Global Terrorism Database, em parceria com o State of Department apresenta a evolução desta realidade:

\begin{tabular}{|l|c|c|c|c|c|c|c|c|}
\hline Ações/Conseq. & $\mathbf{2 0 0 8}$ & $\mathbf{2 0 0 9}$ & $\mathbf{2 0 1 0}$ & $\mathbf{2 0 1 1}$ & $\mathbf{2 0 1 2}$ & $\mathbf{2 0 1 3}$ & $\mathbf{2 0 1 4}$ & $\mathbf{2 0 1 5}$ \\
\hline Atentados & 11.663 & 10.968 & 11.641 & 10.283 & 6.771 & 9.707 & 13.363 & 11.774 \\
\hline Vítimas fatais & 15.709 & 15.311 & 13.193 & 12.533 & 11.098 & 17.891 & 32.727 & 28.328 \\
\hline
\end{tabular}

Fonte: Global Terrorism. Maryland University and State of Department.

A análise aprofundada destes dados aponta que $80 \%$ dos atentados estão concentrados em apenas 20 países, dentre estes, Iraque, Síria, Afeganistão, Líbia, Paquistão, Mali, Iêmem, Nigéria e Somália. Estes números contradizem a teoria da globalização do terrorismo uma vez que os atentados cometidos contra países ocidentais são em menor número comparativamente aos ocorridos na África e Oriente Médio.

Outro ponto que também merece um debate mais amplo, fruto desta análise, é o fato de que $95 \%$ das vítimas fatais serem muçulmanas o que se afasta da teoria do choque de civilizações apregoada pelo cientista político norte-americano, Samuel Huntington, formulada no ano de 1993 e do paradigma da guerra contra o ocidente.

Percebe-se, assim, que esta é mais uma das contradições que emergem de estudos acerca da dialética do terrorismo e de sua globalização.

\section{As novas tecnologias cibernéticas e o ciberterrorismo}

Se por um lado, o discurso da jihad global de Bin Laden possibilitou uma reação conjunta de diversos países acarretando na construção de uma doutrina de contraofensiva global, por outro, os avanços tecnológicos, notadamente, os relacionados ao espaço digital, ratificaram seu caráter internacional.

A massificação da Internet conferiu a grupos ou pessoas acesso a conhecimentos técnicos que anteriormente eram exclusivos das superpotências e de suas Forças Armadas e Agências de Inteligência.

Nesta perspectiva, Naim (2013) assim se posiciona:

(...) a ascensão de poderosos atores não estatais e a rapidíssima difusão da tecnologia para além dos domínios de especialistas erodiram em dois monopólios. O uso da violência dissemina-se e o acesso à tecnologia antes reservada as forças armadas também. (NAIM, 2013, p.179) 
Em decorrência, emerge um novo tipo de ameaça terrorista, com efeitos mais amplos, letais e potencialmente devastadores do que aquele executado com armas convencionais, o chamado ciberterrorismo.

Denning (2000) define ciberterrorismo, como o ataque ou a tentativa de ataque via Internet, a sistemas e programas digitais com o objetivo de intimidar ou coagir um governo para atingir objetivos políticos ou sociais. (DENNING, 2000, p.32).

Os alvos, além das comunidades on-line, podem ser direcionados com maior ênfase para as estruturas críticas de uma sociedade como sistemas de energia elétrica e abastecimento de água, controle de tráfico aéreo da aviação, trens e metrôs, possibilitando o que cientistas da computação classificaram como a hipótese do Armagedon Cibernético. Além dos impactos psicológicos que acarreta, o problema recrudesce por dois motivos principais. A dependência crescente das sociedades desenvolvidas em sistemas e programas digitais, em especial, nos centros urbanos, e pelo fato dos governos mundiais ainda não estarem tecnologicamente preparados para esta ameaça.

Para corroborar com esta assertiva e recorrendo novamente a lição de Naim (2013), este observa que os governos tem sido lentos para se ajustar ao ciberespaço como campo de luta e sem dúvida os agressores desfrutam de ampla margem de manobras e múltiplas oportunidades para atacar as funções fundamentais dos Estados. (NAIM, 2013, p.181).

Vale ressaltar, que existe outra ameaça que embora não tenha ligação com as novas tecnologias, é da mesma magnitude, conhecida por bioterrorismo.

Christopher (1997), conceitua bioterrorismo como:

o uso indevido de substâncias químicas e agentes bacteriológicos nocivos (gases, vírus e bactérias) capazes de provocar graves danos a saúde física e mental da população em geral, incluindo a morte. Dentre estes agentes estão o antraz, a febre hemorrágica, o botulismo, a varíola e a peste bubônica. Os gases letais mais conhecidos são o sarin e mostarda, utilizados por Saddam Hussein contra os curdos no Iraque, na guerra civil da Síria e no metrô de Tóquio, em 1995. (CHRISTOPHER, 1997, p. 36)

O grau de letalidade destas substâncias, tanto químicas como bacteriológicas ocorrem por seus efeitos prolongados confundindo-se com uma epidemia comum, impossíveis de serem detectados a curto prazo, fator que contribui para o aumento de vítimas fatais somados os impactos psicológicos na população.

Vale destacar, que ambos ainda não foram aplicados com a magnitude de um 11 de setembro. Contudo, apresentam-se como tendência para futuros conflitos globais sendo uma 
fonte permanente de preocupação das autoridades internacionais uma vez que propõe uma nova perspectiva de desafios mais complexos e impossíveis de serem mapeados com precisão.

\section{Cenário e perspectivas para a América Latina e Caribe}

É ponto pacífico que a América Latina se constituiu em um dos principais palcos das disputas político-ideológicas durante a Guerra Fria, fomentado tanto pelos EUA como pela extinta URSS. A atuação dos diversos grupos do terrorismo clássico a partir da década de 60 assim como as medidas de contraterrorismo adotadas pelas autoridades governamentais a época, ocasionaram ressentimentos e fraturas sociais até hoje sentidas.

Por sua vez, parcela dos antigos revolucionários ou popularmente conhecidos como guerrilheiros, migraram para as atividades ligadas ao narcotráfico e crimes conexos, integrando organizações criminosas transnacionais a partir da estabilidade política da região nos anos 90. Tal migração, desencadeou uma epidemia de violência e criminalidade de maior intensidade do que as praticadas pelo terrorismo clássico.

Os últimos atentados de repercussão internacional ocorreriam na década de 90, com os dois episódios em Buenos Aires, em 1992 e 1994, já referenciados anteriormente e em 1996, com o ataque do grupo peruano Tupac Amaru a embaixada japonesa em Lima, tomando 490 pessoas como reféns.

Os primeiros, intensificaria a hipótese da presença de células terroristas na região da Tríplice fronteira entre Brasil, Argentina e Paraguai ou em um segundo plano, a questão do financiamento do terrorismo com a transferência de fundos de parte da comunidade islâmica local para países do Oriente Médio.

Todavia, após décadas de monitoramento de agências de inteligência internacionais, a conclusão parcial é de que não há evidências concretas a respeito de qualquer atividade terrorista, incluindo o seu financiamento.

Segundo Amaral (2010), as tentativas de representar esta zona de fronteira como um foco de ameaça terrorista se dão através de um duplo movimento discursivo:

Uma securitização horizontal, que se manifesta no crescente número de atores que tentam associar esse espaço fronteiriço a uma imagem de insegurança, e uma securitização vertical, caracterizada, na esfera pública, de retóricas que alegam haver ameaças cada vez maiores e mais urgentes no local. (...) A força do discurso de securitização se revela precisamente neste ponto, pois, devido a sua influência, se tornou impossível falar da região sem fazer referência a seus problemas de segurança e a suposta vinculação da área com o terrorismo internacional. (AMARAL, 2010, p.257-259). 
A contrário sensu, a atenção especial dispensada a região no quesito segurança está mais relacionada a ação frenética do crime organizado do que propriamente com o terrorismo internacional, embora ambos estejam unidos pelos mesmos métodos de atuação diferenciando-se no quesito das motivações.

Importante dizer, que de certa maneira, os EUA reduziram suas críticas a região, situação evidenciada no recente documento intitulado Country Reports on Terrorism divulgado pelo Departamento de Estado em julho de 2017.

Em termos gerais, o relatório indica que:

(...) ainda há, na América Latina e no Caribe, vulnerabilidades como fronteiras porosas, capacidades limitadas para aplicar a lei e rotas estabelecidas de tráfico de pessoas e drogas, o que oferece oportunidades para grupos terroristas locais e internacionais. A corrupção, as instituições de governo frágeis, a cooperação insuficiente entre agências, uma legislação débil ou inexistente e a falta de recursos seguem sendo as principais causas da falta de vontade política significativa para combater o terrorismo em alguns países do continente.

Observa-se que o documento cita questões estruturais e de inadequação de políticas de governo como fatores que podem, potencialmente, atrair redes terroristas internacionais. A assinatura do acordo de paz entre as FARC com o governo colombiano, em 2016 e a retirada de seu nome da lista de organizações terroristas pelo Departamento de Estado dos EUA e pela União Europeia, pode ser considerada um outro sinal deste novo contexto trazendo novas perspectivas de paz para a região.

Embora permaneça a desconfiança em relação a tríplice fronteira acerca da existência de células terroristas e da duração do acordo assinado pelas FARC, a América Latina possui atualmente o status de região estável no contexto de ações terroristas e outros conflitos bélicos.

Contudo, se por um lado, há baixa probabilidade de uma ação efetiva de células terroristas de origem islâmica na região da América Latina, na prática de atentados tradicionais, aqueles em que são utilizados artefatos explosivos e armas convencionais, por outro, há significativa vulnerabilidade para a ocorrência do ciberterrorismo uma vez que os sistemas de defesa cibernética dos países que compõem o bloco são inexistentes ou se encontram em fase experimental, como no caso do Brasil.

De concreto, os efeitos do terrorismo extremista islâmico se manifesta de forma indireta, na redução dos direitos e garantias individuais pelo aumento do monitoramento e da vigilância eletrônica e digital sobre seus cidadãos e das comunicações on-line privadas. Tal situação é igualmente enfrentada nos países desenvolvidos em geral, segundo relatórios posteriores ao escândalo do vazamento de informações confidenciais pelo site Wikileaks, em 
2013, que comprova a existência de um sistema de monitoramento de comunicações global operado pela National Security Agency (NSA) em conjunto com agência britânica Government Communications Headquarters (GCHQ).

\section{Considerações finais}

Encerrando a presente pesquisa, destaco três pontos principais que emergem do estudo. O primeiro, é que não há registros de ataques praticados por células extremistas islâmicas na América Latina e região do Caribe desde o ano de 1995. Em segundo, até o presente momento, não há evidências concretas que comprovem a presença de grupos oriundos do Oriente Médio nestas regiões, tampouco, dados que indiquem a ocorrência de seu financiamento, apenas suposições.

Em terceiro, doutrinariamente falando, torna-se evidente que a globalização do terrorismo em termos operacionais não ocorreu nos moldes do que se noticia, a contrário sensu de governos e de veiculações na mídia internacional. O que se globalizou foi a contraofensiva de países ocidentais contra o terrorismo, num esforço conjunto dos Estadosmembros da ONU por meio de medidas de segurança mais amplas, dentre estas, a vigilância digital e o monitoramento global na tentativa de mitigar atentados e seus efeitos colaterais.

Em última instância, não está descartada a hipótese do retorno das atividades terroristas à região sul-americana e do caribe com ataques isolados e pontuais, face a dinâmica do terrorismo internacional e a existência de alvos secundários que poderiam ser explorados como propaganda midiática. Não se pode descartar, também, a hipótese de homizio de integrantes destas redes em razão das dimensões continentais e dos motivos elencados anteriormente no Country Reports on Terrorism.

Todavia, tal condição está intimamente associada ao contexto internacional e direcionada atualmente aos países envolvidos direta ou indiretamente com os conflitos da Síria, Iraque e na crise israelo-palestina, o que não é o caso em questão, mas um fator determinante que reduz consideravelmente o grau de risco de atentados na região analisada.

Vale destacar, como ponto positivo, os avanços concentrados na construção de uma doutrina de colaboração técnica entre os países que integram o bloco, fator que deve ser festejado como um importante passo para a consolidação da paz e na identificação e neutralização de possíveis ameaças do terrorismo internacional assim como das ações praticadas por organizações criminosas ligadas ao narcotráfico, situação que na atualidade é seu maior desafio. 


\section{Referências}

AMARAL, Arthur Bernardes do. A Tríplice fronteira e a guerra ao terror, $1^{\mathrm{a}}$ edição, Rio de Janeiro: Apicuri, 2010.

BUSH, George W. Decision Points. New York: Crown Trade Group, 2010.

CRETELLA NETO, José. Teoria geral das organizações internacionais. $2^{\mathrm{a} e d . ~ S a ̃ o ~ P a u l o: ~}$ Saraiva, 2007.

CHRISTOPHER, G.; CIESLAK, T,; PAVLIN. J, ET AL. Biological wafere: the historical perspective: v. $278, \mathrm{n}^{\circ}$ 5: Jama,1997.

CHOMSKY, Noam. Piratas e imperadores: antigos e modernos: o terrorismo internacional no mundo real, tradução Milton Chaves de Almeida, Rio de Janeiro: Bertrand Brasil, 2006.

DWORKIN, Anthony. EE UU-EU: más allá de la guerra contra el terrorismo. Revista Política Exterior, nº 130, SGEL, Distribuição nacional y exterior: Madrid, 2009.

DENNING,E.D. Cyberterrorism - Testimony before the Special Oversight, Panel on Terrorism Committee on Armed Services, U.S. House of Representatives, 2000. Disponível em: http://www.cs.georgetown.edu/denning/infosec/cyberterror.html. Último acesso em 21.03.2018.

FERNÁNDEZ, Alcaide Joaquin. Las atividades terroristas ante el Derecho Internacional Contemporâneo, Madrid: Tecnos, 2000.

GLOBAL TERRORISM. Maryland University and State of Department. The global terrorism. Disponível em: https://www.start.umd.edu/gtd/. Último acesso em 08.02.2018.

HOBSBAWN, Eric. Globalização, democracia e terrorismo. Tradução de José Viegas. São Paulo: Companhia das Letras, 2007.

HOFFMAN, Bruce. Inside terrorism, New York: Columbia University Press, 1998.

LYMAN, Michael e POTTER, Gary. Organized crime: Pearson Prentice Hall, 2004.

NAÍM, Moisés, O fim do poder: nas salas de diretorias ou nos campos de batalha, em igrejas ou Estados, por que estar no poder não é mais o que costumava ser, tradução de Luis Reyes Gil, São Paulo: LeYa, 2013.

SILVA, Carlos Augusto Canêdo. A proteção jurídica internacional contra o terrorismo e a Corte Internacional de Justiça. In: BRANT, Leonardo Nemer Caldeira (Org.) Terrorismo e 
direito: os impactos do terrorismo na comunidade internacional e no Brasil. Rio de Janeiro: Forense, 2003.

UNITED STATES DEPARTAMENT OF STATE PUBLICATION. Country Reports on Terrorism 2016, Disponível em: https://www.state.gov/documents/organization/272488.pdf. Acesso em 20.03.2018.

VARVIN, Sverre. Terrorismo e Vitimização, In: Sverre Varvin e Vamik D. Volkan. (Orgs). Violência ou Diálogo? Reflexões psicanalíticas sobre terror e terrorismo. Tradução de Tânia Maria Zalcberg. São Paulo: Perspectiva, 2008.

WIEVIORKA, Michel. $O$ novo paradigma da violência. Revista Tempo Soc. 1997, vol.9, n.1, USP. Disponível em: http://dx.doi.org/10.1590/S0103-20701997000100002. Último acesso em 04.04.2018.

WOLOSZYN, André Luís. Terrorismo Global: aspectos gerais e criminais. Rio de Janeiro: Biblioteca do Exército, Coleção General Benício, 2010.

WOLOSZYN, André Luís, e FERNANDES, Eduardo de Oliveira. Terrorismo: complexidades, reflexões, legislação e direitos humanos, Curitiba: Juruá, 2017. 